\title{
Mapping of the $m s 8$ male sterility gene in sweet pepper (Capsicum annuum L.) on the chromosome P4 using PCR-based markers useful for breeding programmes
}

\author{
Grzegorz Bartoszewski · Cezary Waszczak • Piotr Gawroński · Iwona Stępień • \\ Hanna Bolibok-Braggoszewska • Alain Palloix • Véronique Lefebvre • \\ Aleksandra Korzeniewska $\cdot$ Katarzyna Niemirowicz-Szczytt
}

Received: 29 November 2011 / Accepted: 31 January 2012/Published online: 10 February 2012

(C) The Author(s) 2012. This article is published with open access at Springerlink.com

\begin{abstract}
The nuclear male sterility gene $m s 8$ is expected to facilitate the production of sweet pepper (Capsicum annuum L.) hybrids as it provides means for hybridization without the labor-intensive hand emasculation of female inbred lines. The development of molecular markers linked to $m s 8$ locus will help the breeding practice for the selection of hybrid parental lines. In this study, $F_{2}$ population resulting from a cross between the sweet pepper male sterile line 320 and the male fertile variety Elf was used to identify DNA markers linked to the $m s 8$ locus. With the use of RAPD-BSA technique, seven markers linked to the $m s 8$ locus were found. Four of them were converted into SCAR markers. In addition, two COSII/CAPS markers linked to the $m s 8$ locus were identified. Comparative mapping with reference pepper maps
\end{abstract}

G. Bartoszewski $(\bowtie) \cdot$ C. Waszczak · P. Gawroński ·

I. Stępień · H. Bolibok-Brągoszewska •

A. Korzeniewska $\cdot$ K. Niemirowicz-Szczytt

Department of Plant Genetics Breeding and

Biotechnology, Warsaw University of Life Sciences

(SGGW), Nowoursynowska 159, 02-776 Warsaw, Poland

e-mail: grzegorz_bartoszewski@sggw.pl

Present Address:

C. Waszczak

VIB Department of Plant Systems Biology, Ghent

University, Technologiepark 927, 9000 Ghent, Belgium

A. Palloix · V. Lefebvre

Unité de Génétique et Amélioration des Fruits et

Légumes, UR 1052, INRA, Domaine Saint-Maurice,

BP 94, 84143 Montfavet Cedex, France indicated that the $m s 8$ locus is located on the lower arm of the pepper chromosome P4. Identified markers are useful for molecular breeding, however, at present markers tightly linked to $m s 8$ locus are still lacking. Identification of molecular markers linked to the $m s 8$ locus and determination of its chromosomal localization are useful for fine mapping and also provide the perspective for $m s 8$ gene cloning.

Keywords Pepper - Genic male sterility · PCR-based markers · Genetic mapping - $m s 8$. Chromosome P4

\section{Introduction}

Pepper is an important vegetable from the Solanaceae family, the production of which has been growing during the last few years. The majority of pepper cultivars belong to Capsicum annuиm L. species, with some varieties belonging to $C$. frutescens $\mathrm{L}$., $C$. baccatum L., C. pubescens R. and P., and C. chinense Jacq. (Bosland and Votava 2000; Korzeniewska 2005). Male sterility is one of the most important traits used in hybrid pepper breeding. Application of male sterility reduces hybrid production costs by excluding the need for manual emasculation of maternal line and elimination of impurities of the seed material originated from self-pollination. Reports 
in the literature describe pepper genic male sterility (ms), cytoplasmic male sterility (CMS), and nuclearcytoplasmic male sterility - a combination of CMS with nuclear fertility restoration genes (Shifriss 1997; Wang and Bosland 2006). At present, the nuclearcytoplasmic male sterility has been used primarily in chili pepper hybrid breeding, while its use in sweet pepper breeding is still limited due to lack of stability of this trait (Shifriss 1997; Zhang et al. 2000; Wang et al. 2004). Genic male sterility systems that employ nuclear male sterility genes are becoming of increasing interest to the breeders (Daskaloff 1972; Korzeniewska et al. 1995; Korzeniewska and Niemirowicz-Szczytt 1998). More than 20 nuclear genes responsible for male sterility in pepper have been reported so far (Wang and Bosland 2006), including the $m s 8$ nuclear recessive gene that was obtained as a result of mutagenesis induced by gamma irradiation applied to the Bulgarian variety Zlaten Medal (Daskaloff 1973, 1974). Expression of male sterility determined by $m s 8$ gene is very stable both in the field and plastic tunnels conditions (Sztangret 1998; Korzeniewska and Niemirowicz-Szczytt, unpublished). Cytological investigations of meiosis showed that microspore formation in $m s 8 / m s 8$ plants is aborted after the second telophase, as cytokinesis is blocked and no viable pollen is formed (Nikolova et al. 2010).

Genic male sterility has the advantage of simple inheritance, thus allowing a relatively quick recovery of female parental lines that contain this characteristic. However, this system has a significant disadvantage in the fact that only $50 \%$ of maternal line plants are male sterile, necessitating the removal of remaining $50 \%$ of plants that are male fertile (Rao et al. 1990; Shifriss 1997). An advanced genic male sterility system based on two nuclear male sterility genes that would increase the number of male sterile plants up to $75 \%$ was proposed by Shifriss and Pilovsky (1993). Alternatively, the fingerprinting of homozygous male sterile genotypes using molecular markers can help in screening seedlings before experimental trials.

Various types of molecular markers used in pepper genetics and molecular breeding successively included restriction fragment length polymorphism (RFLP), random amplified polymorphic DNA (RAPD), amplified fragment length polymorphism (AFLP), simple sequence repeat (SSR), single nucleotide polymorphism (SNP), and transposon-based and locus specific PCR-based markers (Lefebvre 2004). In the last years PCR-based orthologous gene markers referred to as conserved ortholog set COSII were developed (Wu et al. 2006). These markers proved to be widely applicable to genetic studies and molecular breeding in the Solanaceae family, including pepper. The use of COSII markers supported the development of one of the most advanced molecular maps of pepper (Wu et al. 2009).

Recently, several molecular markers linked to genic male sterility genes in pepper have been described. In colored sweet pepper CAPS marker linked to $m s$ gene of unknown origin was identified (Lee et al. 2010a). In chili pepper a codominant SCAR marker linked to the genic male sterility gene $m s_{1}$ and three AFLP markers linked to the $m s_{3}$ gene were found (Lee et al. 2010b, c). So far none of these genes has been located on the pepper chromosomes.

The aim of our study was to identify molecular markers linked to the $m s 8$ gene using PCR-based methodology. Such markers would facilitate the introgression of the $m s 8$ gene into valuable breeding lines and in a hybrid seed production by allowing marker-based selection of male sterile plants at seedling stage. The identification of such markers is also expected to contribute to fine mapping and ultimately to cloning of the $m s 8$ gene.

\section{Materials and methods}

Plant material

The $F_{2}$ mapping population of sweet pepper was obtained from a cross between male sterile line 320 and male fertile variety Elf $(320 \times$ Elf $)$. Line 320 was carrying gamma irradiation-induced $m s 8$ mutation and was kindly provided by Professor S. Daskaloff (Daskaloff 1973). Line 320 was maintained by crossing with the fertility maintainer line (Zlaten Medal). Seeds of the Elf variety were kindly provided by PlanticoZielonki (Zielonki, Poland), a vegetable seed company. The selection of parental lines was based on the results from a study of genetic diversity in Polish pepper breeding materials (Bartoszewski et al., unpublished). A single male sterile plant ( $m s 8 / m s 8)$ from line 320 was used as a female parent in a cross with a single plant of the open pollinated Elf variety $(M s 8 / M s 8)$. The $\mathrm{F}_{1}(M s 8 / m s 8)$ plants were grown in the greenhouse and allowed to self-pollinate. Seeds harvested 
from a single fruit of $F_{1}$ plant were sown to obtain the $\mathrm{F}_{2}$ mapping population. $135 \mathrm{~F}_{2}$ plants were grown in $30 \mathrm{~cm}$ diameter plastic pots in a plastic tunnel. The evaluation of male sterility/fertility was done visually by scoring flower morphology independently by two experienced persons. 100 of fertile $\mathrm{F}_{2}$ plants were selfpollinated to develop $F_{3}$ families. The size of $F_{3}$ families ranged between 20 and 40 plants. $76 \mathrm{~F}_{3}$ families were grown in plastic pots in plastic tunnels. Male fertility in $\mathrm{F}_{3}$ families was evaluated visually by scoring flower morphology and the segregation ratios were calculated. A mapping reference population of pepper Perennial x Yolo Wonder, consisting of 114 DH lines (Lefebvre et al. 2002) was used to map the SCAR markers N2 and V01 and to determine on which chromosome (linkage group) the $m s 8$ locus maps.

\section{DNA extraction}

Total DNA was isolated by CTAB method described by Aldrich and Cullis (1993) with slight modifications as described below. To isolate DNA, leaves from 6 to 8 week old plants were harvested into Eppendorf tubes and deep-frozen. The leaves were ground to fine powder in liquid nitrogen. Total DNA was extracted with pre-warmed extraction buffer (1\% CTAB, $100 \mathrm{mM}$ Tris-HCl pH 8.0, $2 \mathrm{M} \mathrm{NaCl}, 20 \mathrm{mM}$ EDTA, $2 \%$ PVP, and $0.25 \% \quad \beta$-mercaptoethanol) from ca. $250 \mathrm{mg}$ of frozen tissue. The mixture was incubated at $55^{\circ} \mathrm{C}$ for $20 \mathrm{~min}$ in water bath with gentle shaking and extracted three times with chloroform:isoamyl alcohol (24:1). After chloroform extraction, the mixtures were centrifuged, DNA was precipitated with isopropanol, washed with $70 \%$ ethanol, air-dried, and resuspended in $10 \mathrm{mM}$ Tris- $\mathrm{HCl} \mathrm{pH} 8.0$ solution. Then the samples were treated with RNaseA as described by Sambrook et al. (1989). The purity and quantity of isolated DNA was evaluated by electrophoresis and gel staining with ethidium bromide. DNA concentration was adjusted to $10 \mathrm{ng} / \mu \mathrm{l}$.

\section{RAPD analysis}

The RAPD analysis was done using the Bulked Segregant Analysis (BSA) approach (Michelmore et al. 1991). Based on the visual evaluation of the fertility in the $F_{2}$ population and in $F_{3}$ families, individual homozygous plants were selected from the $\mathrm{F}_{2}$ population and their DNA was included in the bulked samples. The male fertile bulked DNA sample (F) consisted of DNA from 10 fertile $F_{2}$ plants whose $\mathrm{F}_{3}$ progenies were $100 \%$ fertile. The male sterile bulked DNA sample (S) consisted of DNA from 10 male sterile $\mathrm{F}_{2}$ plants. The bulked DNA samples were obtained by mixing equal volumes of DNA from all of the selected plants. The DNA bulks were screened with a total of 550 arbitrary 10-mer primers [primer kits OPA to OPZ and primers OPAC09, OPAC17, OPAD12, OPAF07, OPAF15, OPAG01, OPAG17, OPAH14, OPAI10, OPAJ01, OPAJ02, OPAJ06, OPAJ18, OPAK16, OPAM02, OPAO07, OPAO12, OPAO14, OPAR13, OPAT15 from Operon Technology (Alameda, CA, USA); primers BC231, BC256, BC450, BC503, BC515, BC519, BC526, BC592, BC600, BC605 from BC Biotech (Vancouver, Canada)]. Polymerase chain reactions (PCR) were performed as reported previously by Olczak-Woltman et al. (2009). Reactions contained $75 \mathrm{mM}$ Tris- $\mathrm{HCl}$ $\mathrm{pH} 8.8,20 \mathrm{mM}\left(\mathrm{NH}_{4}\right)_{2} \mathrm{SO}_{4}, 0.01 \%$ Tween $20,2.5 \mathrm{mM}$ $\mathrm{MgCl}_{2}, 0.2 \mathrm{mM}$ of each dNTP, $2 \mu \mathrm{g}$ of bovine serum albumin, 1.25 U Taq polymerase (Fermentas, Vilnius, Lithuania), $1 \mu \mathrm{M}$ of arbitrary primer, and $20 \mathrm{ng}$ of DNA template. The PCR cycles were as follows: initial incubation at $95^{\circ} \mathrm{C}$ for $1 \mathrm{~min}$, then 10 cycles: $94^{\circ} \mathrm{C}$ for $5 \mathrm{~s}, 37^{\circ} \mathrm{C}$ for $30 \mathrm{~s}, 72^{\circ} \mathrm{C}$ for $30 \mathrm{~s}$, followed by 35 cycles of: $94^{\circ} \mathrm{C}$ for $5 \mathrm{~s}, 37^{\circ} \mathrm{C}$ for $30 \mathrm{~s}, 72^{\circ} \mathrm{C}$ for $60 \mathrm{~s}$, and final extension at $72^{\circ} \mathrm{C}$ for $7 \mathrm{~min}$. PCR reactions were carried out in the thermocycler PTC-200 (MJ Research, Watertown, MA, USA). Amplified DNA fragments were separated by electrophoresis in $1.5 \%$ agarose gel containing ethidium bromide (Sambrook et al. 1989) and visualized with UV light. RAPD analysis of bulks was carried out in two replications.

\section{SCAR marker development}

Polymorphic RAPD amplicons were purified from gel, then reamplified with their respective primers, separated by electrophoresis, and again purified from the gel. Next, the amplicons were cloned into pCRIITOPO plasmid with the use of TOPO Cloning Kit (Invitrogen, Carlsbad, CA, USA). The recombinant plasmids were isolated and the inserts were sequenced. The resulting sequences were assembled using Sequencher 4.5 (GeneCodes, Ann Arbor, MI, USA). To have better chance to design reliable SCAR primers for two RAPD markers P15-530 and Z05-760 (closest to $m s 8$ locus) genome walking was performed using 
Vectorette PCR (Arnold and Hodgson 1991). Vectorette DNA libraries were constructed by digesting genomic DNA from line 320 with one of the six restriction enzymes (BamHI, ClaI, EcoI, HindIII, $P v u \mathrm{II}$, and $S s p \mathrm{I}$ ) followed by ligations with adapters compatible with these enzymes as described by the Vectorette system manufacturer (Sigma, St. Louis, MO, USA). The libraries were subjected to primary PCR using the Vectorette-adapter-specific primers and marker specific primers according to the manufacturer's protocol. Primary PCR reactions were diluted 1:100 and used as a template for a secondary PCR using nested Vectorette primer and marker specific primers. Thus obtained amplicons were sequenced and assembled. Final P15-530 and Z05-760 fragments were PCR-amplified, sequenced and verified for nucleotide homology with the primary RAPD marker sequences.

The consensus sequences were deposited at the NCBI (GenBank accession numbers are given in Table 1). The sequences were analyzed by comparison with those publicly accessible in the GenBank and in the Sol Genomics Network (July 2011) with the use of the BLAST algorithm. RAPD marker sequences were used to design a set of sequence specific primers using Oligo 7 software (Molecular Biology Insites Inc., MA, USA). The PCR reaction with these primers was performed on bulked DNA samples as well as on $\mathrm{F}_{2}$ mapping population in order to verify the cosegregation with initial RAPD markers. Different PCR conditions were tested to find the optimum for a given pair of primers. Optimized PCR conditions and the respective primer pairs are shown in Table 2.

Markers specific for the lower arm of the pepper chromosome P4

The markers mapped by Wu et al. (2009) on the lower arm of the pepper chromosome P4 were tested on the parental lines of the mapping population. The tested markers consisted of fourteen COSII markers (C2_At4g77250,C2_At1g71810,C2_At1g78230,C2_ At4g09010, C2_At1g09920, C2_At1g27530, C2_At3g 16150,C2_At1g46480,C2_At5g25900,C2_At1g42950, C2_At1g75350, C2_At1g63610, C2_At1g20575, and C2_At1g76080) and five SSR markers (Hpms1-165, GMPS2003, CAN130829, BM61461, and CA523715). A standard PCR reaction was performed by the application of Taq polymerase according to manufacturer's instructions (Fermentas). The PCR cycles were as follow: initial incubation at $94^{\circ} \mathrm{C}$ for $3 \mathrm{~min}$, then 36 cycles: $94^{\circ} \mathrm{C}$ for $30 \mathrm{~s}, 55^{\circ} \mathrm{C}$ for $30 \mathrm{~s}, 72^{\circ} \mathrm{C}$ for $3 \mathrm{~min}$, and final extension at $72^{\circ} \mathrm{C}$ for $10 \mathrm{~min}$. The amplification products were separated on agarose gel, purified and sequenced. The readouts were analyzed using Sequencher 4.5 software (GeneCodes). The C2_At5g25900 and C2_At1g71810 markers were transformed into the COSII/CAPS markers in order to map them in the $320 \times$ Elf $\mathrm{F}_{2}$ mapping population. In the case of the C2_At5g25900 marker, the primers SNP-F GACACTGCTGCACAGAGCTT and SNP-R CAAACCCAGTGTATTCCCACA were designed, and the PCR products were digested with the $M b o \mathrm{I}$ enzyme (Fermentas). The primers obtained from the Sol Genomics Network (http://solgenomics.net) were applied to the C2_At1g71810 marker, and the amplification product was digested with the XapI enzyme (Fermentas). The digestion products were separated on $1.5 \%$ agarose gels and scored.

\section{Linkage analysis}

Markers segregating in accordance with 3:1 ratio (dominant) or 1:2:1 ratio (codominant) at $p=0.05$ or less as determined by the Chi-square test were used in mapping. The segregation data were analysed using the JoinMap 4.0 software package. The linkage group including $m s 8$ was established initially at LOD $=3.0$, then at LOD $=2.0$ using the Kosambi function.

\section{Results and discussion}

Male sterility of flowers was evaluated on $F_{2}$ plants obtained by crossing line 320 and var. Elf. Out of 135 plants in the $F_{2}$ population, 100 were fertile and 35 male sterile. This segregation fitted the theoretical ratio of 3:1 with a Chi-square value of 0.039 and a $p$-value of 0.84 , indicating that the male sterility was determined by a single recessive gene as described before (Daskaloff 1973, 1974). $F_{3}$ progenies were obtained through self-pollination of 76 of the 100 fertile $F_{2}$ plants, and male sterility was assessed in these families. In total, $31 \mathrm{~F}_{3}$ families were $100 \%$ fertile, and $45 \mathrm{~F}_{3}$ families segregated for male sterility. Thus, the genotypes of $111 \mathrm{~F}_{2}$ plants constituting the $\mathrm{F}_{2}$ mapping population was completely determined; the genotypes of remaining 24 fertile plants were 
Table 1 GenBank accession numbers and the results of blast analysis of RAPD marker sequences

\begin{tabular}{|c|c|c|c|c|}
\hline $\begin{array}{l}\text { RAPD } \\
\text { marker }\end{array}$ & $\begin{array}{l}\text { GenBank } \\
\text { Acc. No. }\end{array}$ & $\begin{array}{l}\text { Sequence } \\
\text { length (bp) }\end{array}$ & BLAST hits & e-value \\
\hline $\mathrm{P} 15-530$ & JN603671 & $1210 / 537^{\mathrm{a}}$ & No significant similarity & n.a. \\
\hline Z05-760 & JN603676 & $1406 / 759^{\mathrm{a}}$ & $\begin{array}{l}\text { Capsicum annuum clone BAC CaCM403E16 (GU048901) } \\
\text { Solanum tuberosum chromosome } 5 \text { clone RH167J23 (AC232111) }\end{array}$ & $\begin{array}{l}2.09 \mathrm{e}-65 \\
9.55 \mathrm{e}-40\end{array}$ \\
\hline V17-320A & JN603674 & 317 & Nicotiana tabacum retrotransposon Gypsy 9-1 (AB604787) & $1.12 \mathrm{e}-7$ \\
\hline V17-320B & JN603677 & 313 & Capsicum апnиит clone BAC CaCM328A06 (JF330775) & $8.65 \mathrm{e}-19$ \\
\hline W06-520 & JN603675 & 518 & $\begin{array}{l}\text { Capsicum anпиит clone BAC CaCM278G16 (JF330774) } \\
\text { Capsicum annиum clone BAC CaCM642F15 (JF330777) } \\
\text { Capsicum annиum clone BAC CaCM557C04 (GU048903) }\end{array}$ & $\begin{array}{l}2.27 \mathrm{e}-22 \\
8.65 \mathrm{e}-19 \\
2.11 \mathrm{e}-13\end{array}$ \\
\hline N16-800 & JN603670 & 806 & Capsicum аппиит KS24 cDNA, mRNA sequence (GD122580) & $2 \mathrm{e}-24$ \\
\hline V01-1000 & JN603673 & 1036 & Capsicum annuum clone BAC CaCM409M06 (GU048902) & $5.34 \mathrm{e}-17$ \\
\hline Q07-1100 & JN603672 & 1101 & $\begin{array}{l}\text { Capsicum anпиum clone BAC CaCM642F15 (JF330777) } \\
\text { Capsicum annиum clone BAC CaCM388I15 (JF330776) } \\
\text { Capsicum annuum retrotransposon homolog gene } \\
\text { B47 pseudogene (AF121443) }\end{array}$ & $\begin{array}{l}1.47 \mathrm{e}-97 \\
1.46 \mathrm{e}-60 \\
1.36 \mathrm{e}-54\end{array}$ \\
\hline
\end{tabular}

The description presents the three most similar sequences with the expected threshold (e-value) less than 1e-7. GenBank accession numbers of BLAST hits are given in brackets, $b p$ base pairs, n.a. not available

a Final sequence length obtained using genome walking approach is provided first, followed by the original RAPD marker sequence length

recognized as dominant homozygote or heterozygote $(M s 8 /-)$. Ten plants determined as dominant homozygotes $(M s 8 / M s 8)$, and 10 determined as recessive homozygotes $(\mathrm{ms} 8 / \mathrm{ms} 8)$ were selected for further study. Their DNA was included in male fertile (F) and male sterile (S) bulked DNA samples. Polymorphic amplicons were identified for 31 out of 550 tested RAPD primers, and used to distinguish between the F and the $\mathrm{S}$ bulked DNA samples. The polymorphism consisted of the presence or absence of a DNA amplicon on a gel or a difference in fluorescence intensity between the two bulks. The primers that differentiated the bulked samples were tested on individual $F_{2}$ plants that were originally included in the $\mathrm{F}$ and the $\mathrm{S}$ bulked samples, and on the parental lines. Seven RAPD primers were identified that delivered repeatable results. These primers were tested on the $\mathrm{F}_{2}$ mapping population. The amplicons N16800, P15-530, V17-320, W06-520, and Z05-760 were linked in a coupling phase, and the amplicons Q071100 , V01-1000 were linked in the repulsion phase with the recessive $m s 8$ allele. Their segregation fitted the $3: 1$ ratio expected from the mapping $F_{2}$ population from the $320 \times$ Elf cross.

An attempt was made to convert the identified RAPD markers into SCAR markers. All of the seven polymorphic RAPD amplicons were successfully cloned and sequenced. The V17-320 amplicon delivered two types of sequences: V17-320A (3 clones) and V17-320B (2 clones). Initial P15-530 and Z05-760 sequences were extended using the genome walking method. The obtained sequences were compared with those accessible in the public databases. Table 1 sums up the results of the analysis. Five sequences (Z05-760, V17-320B, W06-520, V01-1000, and Q07-1100) revealed extensive similarity to at least eight pepper BAC clones that are rich in LTR/Gypsy-like retrotransposons as reported by Park et al. (2011). The N16-800 sequence showed significant similarity to the cDNA pepper clone KS24. For the P15-530 sequence, no similarity to any known sequences deposited in the GenBank or the Sol Genomics Network was identified. Similarity of RAPD sequences to retroelements was rather unexpected and suggested that conversion of these RAPD markers into the SCAR markers would be difficult.

Using the obtained sequences, a set of specific pairs of primers was designed and tested on the parental lines and the $\mathrm{F}_{2}$ plants that were included in the bulked DNA samples. As a result, it was possible to transform four RAPD markers: N16-800, V01-1000, P15-530 and V17-320A into SCAR markers, named respectively: 
Table 2 Description of SCAR markers linked to locus $m s 8$ in pepper

\begin{tabular}{|c|c|c|c|c|}
\hline $\begin{array}{l}\text { SCAR } \\
\text { marker }\end{array}$ & $\begin{array}{l}\text { Primer names and sequences } \\
\left(5^{\prime}-3^{\prime}\right)\end{array}$ & $\begin{array}{l}\text { Optimized PCR cycling } \\
\text { conditions }\end{array}$ & $\begin{array}{l}\text { Amplicon } \\
\text { length (bp) }\end{array}$ & $\begin{array}{l}\text { Original RAPD } \\
\text { marker name }\end{array}$ \\
\hline $\mathrm{P} 2$ & $\begin{array}{l}\text { P2F-AAGCCAACAGGGGGTATCGCATAAGCA } \\
\text { P2R-GGAAGCCAACAACACCCATATTTTCCA }\end{array}$ & $\begin{array}{l}95^{\circ} \mathrm{C}-4 \mathrm{~min} . \\
30 \text { cycles: } 95^{\circ} \mathrm{C}-30 \\
\mathrm{~s} / 68.1^{\circ} \mathrm{C}-1 \mathrm{~min} .^{\mathrm{a}} \\
72^{\circ} \mathrm{C}-5 \mathrm{~min} .\end{array}$ & 537 & P15-530 \\
\hline V17 & $\begin{array}{l}\text { VF-ACCGGCTTGTCCCCGTGGA } \\
\text { VR-ACCGGCTTGTATGACTCTCTA }\end{array}$ & $\begin{array}{l}95^{\circ} \mathrm{C}-4 \mathrm{~min} . \\
10 \text { cycles: } 95^{\circ} \mathrm{C}-30 \\
\mathrm{~s} / 70^{\circ}-0.2^{\circ} \mathrm{C} \text { per cycle}-1 \mathrm{~min} . \\
30 \text { cycles: } 95^{\circ} \mathrm{C}-30 \\
\mathrm{~s} / 68^{\circ} \mathrm{C}-1 \mathrm{~min}^{\mathrm{a}} \\
72^{\circ} \mathrm{C}-5 \mathrm{~min} .\end{array}$ & 317 & V17-320 \\
\hline $\mathrm{N} 2$ & $\begin{array}{l}\text { N16/2F-ATACCCAAATCCCACCGTTCA } \\
\text { N16/2R-AATAGGACTCAAACTTCGACGAAA }\end{array}$ & $\begin{array}{l}95^{\circ} \mathrm{C}-4 \mathrm{~min} . \\
30 \text { cycles: } 95^{\circ} \mathrm{C}-30 \\
\mathrm{~s} / 63^{\circ} \mathrm{C}-1 \mathrm{~min} . / 72^{\circ} \mathrm{C}-1 \min .30 \mathrm{~s} \\
72^{\circ} \mathrm{C}-5 \mathrm{~min} .\end{array}$ & 265 & N16-800 \\
\hline V01 & $\begin{array}{l}\text { V1_100F2-ACATGGCCTGAGTATCGTGAA } \\
\text { V1_100R2-TGTAACCATCTCCCAAATAGAGC }\end{array}$ & $\begin{array}{l}95^{\circ} \mathrm{C}-4 \mathrm{~min} . \\
30 \text { cycles: } 95^{\circ} \mathrm{C}-30 \\
\mathrm{~s} / 64^{\circ} \mathrm{C}-1 \mathrm{~min} . / 72^{\circ} \mathrm{C}-1 \mathrm{~min} .30 \mathrm{~s} \\
72^{\circ} \mathrm{C}-5 \mathrm{~min} .\end{array}$ & 358 & V01-1000 \\
\hline
\end{tabular}

SCAR primers, optimized PCR conditions, expected amplicon sizes, and corresponding RAPD marker names are provided, $b p$ base pairs

a two-step PCR

N2, V01, P2 and V17 (Table 2). Three SCAR markers segregated precisely like their RAPD equivalents in the $320 \times$ Elf $F_{2}$ population. The SCAR_V17 marker designed on the basis of the V17-320A sequence segregated differently from its initial RAPD marker (in 6 out of 135 plants), but it was still linked to the $m s 8$ locus and was placed in the $m s 8$ linkage group. RAPD marker V17-320 was not monomorphic (Table 1) and it could possibly explain different segregation of RAPD V17-320 and SCAR_V17 markers.

Two of the four SCAR markers, namely SCAR_V01 and SCAR_N2 differentiated the parents of the reference mapping population Perennial $x$ Yolo Wonder and were placed on the genetic map of that population. These markers were located in the $\mathrm{P} 4$ linkage group between the AFLP CAE120p and CEX168p markers at positions 95.5 and $104.1 \mathrm{cM}$, and above the RFLP markers TG62 and TG65 located at positions 113.6 and $120.2 \mathrm{cM}$. We further looked for additional markers carried by the chromosome P4.

A set of COSII and SSR markers that were specific for the lower arm of the P4 chromosome in the map of pepper based on the interspecific cross between $C$. frutescens var. BG 2814-6 and C. апnиum cv. NuMex RNaky (Wu et al. 2009) was tested on the parental lines of the $320 \times$ Elf $F_{2}$ mapping population. Only two of the 19 markers tested showed SNP polymorphism which in turn allowed for their conversion into codominant COSII/CAPS markers and subsequent mapping them into the $320 \times$ Elf $F_{2}$ population.

Linkage analysis showed that three RAPD, four SCAR and two COSII/CAPS markers were linked to the $m s 8$ locus (Fig. 1). The two cosegregating SCAR_P2 and RAPD Z05-760 are the closest markers $(4.6 \mathrm{cM})$ to the $m s 8$ locus. Both markers were dominant and linked in the coupling phase to the $m s 8$ recessive allele. The dominant markers SCAR_V17 and RAPD W06-520, were located at a greater distance ( 6.8 and $7.4 \mathrm{cM}$, respectively) from the $m s 8$ locus. The codominant marker C2_At1g71810/XapI and the dominant markers SCAR_N2, RAPD Q07-1100 and SCAR_V01 were still more distant (15.2, 16.1, 17.5, and $18.1 \mathrm{cM}$ respectively). The markers RAPD Q071100 and SCAR_V01 were linked in a coupling phase to the dominant $M s 8$ allele. All the mentioned markers were located on the same side above the $m s 8$ locus at 
P4

C. frutescens var. BG 2814-6 × C. annuum cv. NuMex RNaky

(Wu et al., 2009)

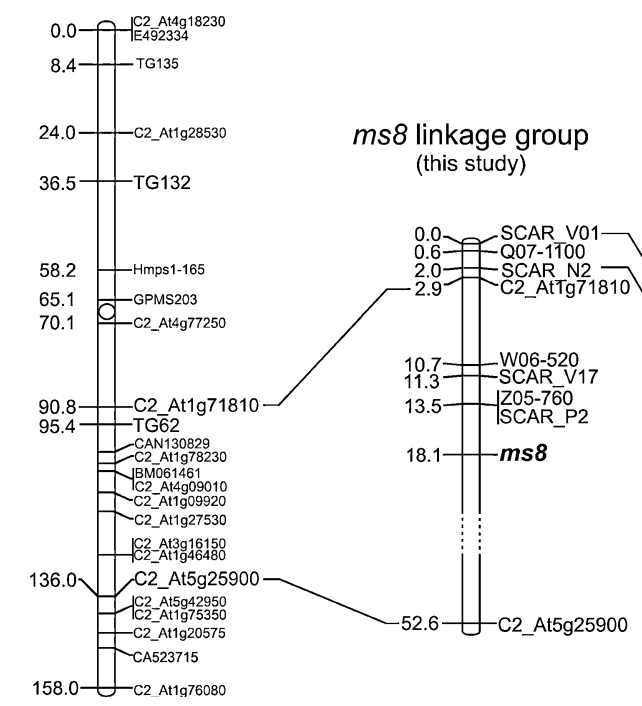

C. frutescens var. BG $2814-6 \times C$. annum
P4

Perennial $x$ Yolo Wonder

(Lefebvre et al., 2002)

0,0-R11_0.4

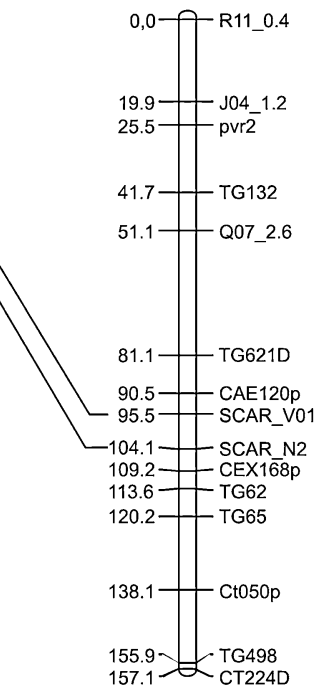

Fig. 1 Comparison of the $m s 8$ locus linkage group with genetic maps of the chromosome $\mathrm{P} 4$ of pepper derived from two pepper reference maps. Left simplified scheme of the P4 linkage group derived from the map of $C$. frutescens var. BG 2814-6 $\times C$. annuиm cv. NuMex RNaky pepper, published earlier by $\mathrm{Wu}$ et al. (2009). Middle the $m s 8$ linkage group. Right simplified P4

$\mathrm{LOD}=3$. At the lower value of $\mathrm{LOD}=2$, the C2_At5g25900/MboI marker was placed on the opposite side below the $m s 8$ locus (Fig. 1).

The mapping of the two SCAR markers linked to the $m s 8$ locus in the P4 linkage group of the Perennial $\mathrm{x}$ Yolo Wonder population and the mapping near the $m s 8$ locus of the two COSII markers present in the P4 linkage group of the $C$. frutescens var. BG 2814-6 $\times$ C. annuum cv. NuMex RNaky indicate that the $m s 8$ locus is located on the lower arm of the pepper chromosome $\mathrm{P} 4$. In addition to the $m s 8$ locus, a number of other important traits of pepper were mapped to the P4 chromosome: the pvr2 locus for PVY resistance (Caranta et al. 1997; Lefebvre et al. 2002), the $C 2$ locus for fruit color (Thorup et al. 2000), QTLs for fruit weight and shape (Barchi et al. 2009; Zygier et al. 2005), and QTL for Phytophthora capsici resistance (Thabuis et al. 2004). It has to be considered in the breeding programmes aimed to introgress $m s 8$ gene into the different breeding lines. It seems that QTLs for fruit weight and shape are closely linked to $m s 8$ locus and selection of recombinants may be necessary. linkage group derived from the genetic map of Perennial x Yolo Wonder, published earlier by Lefebvre et al. (2002), with SCAR_V01 and SCAR_N2 markers mapped. Markers common for particular linkage groups were connected with solid lines. The $m s 8$ linkage group is presented in a different scale than the two other linkage groups

The markers described in this study are the first markers identified as linked to the $m s \delta$ gene. The application of a single of these newly identified markers in breeding programmes is limited, because the nearest ones to the $m s 8$ locus, the SCAR_P2 and the RAPD Z05-760, are coupled with the $m s 8$ recessive allele, and are dominant. To circumvent this problem, we consequently propose to use them in combination with the SCAR_N2 or the SCAR_V01 markers linked to the $M s 8$ dominant allele. However, as those markers are rather distant from the $m s 8$ locus, other narrowly linked markers have to be identified to be used reliably in segregating populations. The codominant marker COS/CAPS C2_At1g71810/XapI is also too distant from the $m s 8$ locus $(15.2 \mathrm{cM})$ to be used reliably.

The lower arm of the pepper chromosome $\mathrm{P} 4$ shows synteny with the lower arm of chromosome T4 in tomato and chromosome IV in potato (Wu et al. 2009; $\mathrm{Wu}$ and Tanksley 2010). This relatedness provides an opportunity for a transfer of tomato markers to pepper, and thus for identification of new markers that are placed in proximity to the $m s 8$ locus, fine mapping and ultimately cloning of the $m s 8$ gene. 
Acknowledgments The authors would like to thank Prof. Stefan Daskaloff for providing seeds of sweet pepper line 320 carrying $m s 8$ gene and variety Zlaten Medal. This work was supported by the Polish Ministry of Agriculture and Rural Development. We also thank two anonymous reviewers for valuable comments and suggestions that helped us to improve an early version of the manuscript.

Open Access This article is distributed under the terms of the Creative Commons Attribution License which permits any use, distribution, and reproduction in any medium, provided the original author(s) and the source are credited.

\section{References}

Aldrich KJ, Cullis CA (1993) CTAB DNA extraction from plant tissue. Plant Mol Biol 11:128-141

Arnold C, Hodgson IJ (1991) Vectorette PCR: a novel approach to genomic walking. PCR Methods Appl 1:39-42

Barchi L, Lefebvre V, Sage-Palloix AM, Lanteri S, Palloix A (2009) QTL analysis of plant development and fruit traits in pepper and performance of selective phenotyping. Theor Appl Genet 118:1157-1171

Bosland PW, Votava EJ (2000) Peppers: vegetable and spice capsicums. CABI Publishing, Wallingford

Caranta C, Lefebvre V, Palloix A (1997) Polygenic resistance of pepper to potyviruses consists of a combination of isolatespecific and broad-spectrum quantitative trait loci. Mol Plant Microbe Interact 10:872-878

Daskaloff S (1972) Male sterile pepper (C. annuum L.) mutants and their utilization in heterosis breeding. In: Proceedings of Eucarpia meeting on genetics and breeding of Capsicum, Torino, pp 205-210

Daskaloff S (1973) Investigation of induced mutants in Capsicum annuиm L. III. Mutants in the variety Zlaten Medal. Genet Plant Breed 6:419-429

Daskaloff S (1974) Investigation of induced mutants in sweet pepper (Capsicum annuum L.). In: Proceedings of the 1st meeting of the Capsicum breeding and genetics, Budapest, 1-4 July 1974, pp 81-90

Korzeniewska A (2005) Pepper production in the field. Hortpress, Warsaw (in Polish)

Korzeniewska A, Niemirowicz-Szczytt K (1998) Characteristics of two different male sterile lines of sweet pepper (Capsicum annum L.) with emphasis on hybrid seed production ability. Folia Hortic 10:15-25

Korzeniewska A, Nikolova V, Niemirowicz-Szczytt K (1995) The chlorophyll deficient form-an attractive parental component for sweet pepper (Capsicum annuum L.) $\mathrm{F}_{1}$ hybrids. In: Proceedings of the IXth Eucarpia meeting on genetics and breeding on Capsicum and eggplant, Budapest, pp 103-106

Lee J, Han JH, An CG, Lee WP, Bok Jae, Yoon JB (2010a) A CAPS marker linked to a genic male-sterile gene in the colored sweet pepper, 'Paprika' (Capsicum annuиm L.). Breed Sci 60:93-98

Lee J, Yoon JB, Han JH, Lee WP, Do JW, Ryu H, Kim SH, Park HG (2010b) A codominant SCAR marker linked to the genic male sterility gene $\left(m s_{1}\right)$ in chili pepper (Capsicum апnиит). Plant Breed 129:35-38

Lee J, Yoon JB, Han JH, Lee WP, Kim SH, Park HG (2010c) Three AFLP markers tightly linked to the genic male sterility $m_{3}$ gene in chili pepper (Capsicum annuum L.) and conversion to a CAPS marker. Euphytica 173:55-61

Lefebvre V (2004) Molecular markers for genetics and breeding: development and use in pepper (Capsicum spp.). In: Lörz H, Wenzel G (eds) Biotechnology in agriculture and forestry, vol 55. Springer-Verlag, Berlin-Heidelberg, pp 189-214

Lefebvre V, Pflieger S, Thabuis A, Caranta C, Blattes A, Chauvet J, Daubèze A, Palloix A (2002) Towards the saturation of the pepper linkage map by alignment of three intraspecific maps including known-function genes. Genome 45:839-854

Michelmore RW, Paran I, Kesseli RV (1991) Identification of markers linked to disease resistance genes by bulked segregant analysis: a rapid method to detect markers in specific genomic regions using segregating populations. Proc Natl Acad Sci USA 88:9828-9832

Nikolova V, Todorova V, Stefanova Y, Tomlekova N (2010) Cytological particularities in nuclear and nuclear-cytoplasmic male sterile pepper lines. Caryologia 63:262-268

Olczak-Woltman H, Bartoszewski G, Madry W, NiemirowiczSzczytt K (2009) Inheritance of resistance to angular leaf spot (Pseudomonas syringae pv. lachrymans) in cucumber and identification of molecular markers linked to resistance. Plant Pathol 58:145-151

Park M, Jo SH, Kwon JK, Park J, Ahn JH, Kim S, Lee YH, Yang TJ, Hur CG, Kang BC, Kim SD, Choi D (2011) Comparative analysis of pepper and tomato reveals euchromatin expansion of pepper genome caused by differential accumulation of Ty3/Gypsy-like elements. BMC Genomics $12: 85$

Rao MK, Devi KU, Arundhati A (1990) Applications of genic male sterility in plant breeding. Plant Breed 105:1-25

Sambrook J, Fritsch EF, Maniatis T (1989) Molecular cloning. A laboratory manual, 2nd edn. Cold Spring Harbor Laboratory Press, Cold Spring Harbor

Shifriss C (1997) Male sterility in pepper (Capsicum annuum L.). Euphytica 93:83-88

Shifriss C, Pilovsky M (1993) Digenic nature of male sterility in pepper (Capsicum annuum L.). Euphytica 67:111-112

Sztangret J (1998) Male sterility in hybrid seed production of sweet pepper (Capsicum annuиm L.). MSc Thesis, Warsaw University of Life Sciences, Warsaw (in Polish)

Thabuis A, Lefebvre V, Bernard G, Daubeze AM, Phaly T, Pochard E, Palloix A (2004) Phenotypic and molecular evaluation of a recurrent selection program for a polygenic resistance to Phytophthora capsici in pepper. Theor Appl Genet 109:342-351

Thorup TA, Tanyolac B, Livingstone KD, Popovsky S, Paran I, Jahn M (2000) Candidate gene analysis of organ pigmentation loci in the Solanaceae. Proc Natl Acad Sci USA 97:11192-11197

Wang D, Bosland PW (2006) The genes of Capsicum. HortScience 41:1169-1187

Wang LH, Zhang BX, Lefebvre V, Huang SW, Daubèze AM, Palloix A (2004) Qtl analysis of fertility restoration in cytoplasmic male sterile pepper. Theor Appl Genet 109: $1058-1063$ 
Wu FN, Tanksley SD (2010) Chromosomal evolution in the plant family Solanaceae. BMC Genomics 11:182

Wu FN, Mueller LA, Crouzillat D, Petiard V, Tanksley SD (2006) Combining bioinformatics and phylogenetics to identify large sets of single-copy orthologous genes (COSII) for comparative, evolutionary and systematic studies: a test case in the euasterid plant clade. Genetics 174:1407-1420

Wu FN, Eannetta NT, Xu YM, Durrett R, Mazourek M, Jahn MM, Tanksley SD (2009) A COSII genetic map of the pepper genome provides a detailed picture of synteny with tomato and new insights into recent chromosome evolution in the genus Capsicum. Theor Appl Genet 118:1279-1293

Zhang BX, Huang SW, Yang GM, Guo JZ (2000) Two RAPD markers linked to a major fertility restorer gene in pepper. Euphytica 113:155-161

Zygier S, Chaim AB, Efrati A, Kaluzky G, Borovsky Y, Paran I (2005) QTL mapping for fruit size and shape in chromosomes 2 and 4 in pepper and a comparison of the pepper QTL map with that of tomato. Theor Appl Genet 111: 437-445 